Borneo Journal of Science \& Technology, Volume (2), Issue (2), Pages: 01-05

DOI: http://doi.org/10.3570/bjost.2020.2.2-01

e-ISSN: 2672-7439

(c) 2018, UCTS Publisher.

\begin{tabular}{lll}
\hline Submitted: $11^{\text {th }}$ February 2020 & Accepted: $01^{\text {st }}$ March 2020 & Published: $31^{\text {th }}$ July 2020
\end{tabular}

\title{
Determination of Crop Coefficient Values of Chili by Drainage Lysimeter
}

\author{
${ }^{1 *}$ Md. Nazmul Islam, ${ }^{2}$ Nirmal Chandra Shil, ${ }^{3}$ Farjana Sultana, ${ }^{3} \mathrm{Md}$ Ataur Rahman \\ ${ }^{1}$ International University of Business Agriculture and Technology, IUBAT, Dhaka, Bangladesh \\ ${ }^{2}$ Soil Science Division, Bangladesh Agricultural Research Institute, Gazipur, Bangladesh \\ ${ }^{3}$ College of Agricultural Sciences, IUBAT, Dhaka, Bangladesh
}

\begin{abstract}
A study on chili (cv. BARI Morich 3) was conducted in the drainage Lysimeter located in the Central Research Farm, BARI, Gazipur ( $24^{\circ} 05^{\prime} \mathrm{N}$ latitude and $90^{\circ} 25^{\prime}$ E longitudes) during rabi 2017-2018. The objectives of the study were to find out the location specific crop coefficient $(\mathrm{Kc})$ values for chili and to estimate the water requirement for winter chili. Four regimes of irrigation water were applied on the basis of depletion over field capacity (FC) at pre-determined intervals such as $\mathrm{T}_{1}$ : Irrigation up to $\mathrm{FC}$ at 10 days interval, $\mathrm{T}_{2}$ : Irrigation up to $\mathrm{FC}$ at 15 days interval, $\mathrm{T}_{3}$ : Irrigation up to $\mathrm{FC}$ at 20 days interval and $\mathrm{T}_{4}$ : Irrigation up to $\mathrm{FC}$ at 25 days interval. As such, 11, 8, 6 and 4 irrigations were needed for $\mathrm{T}_{1}, \mathrm{~T}_{2}, \mathrm{~T}_{3}$ and $\mathrm{T}_{4}$, respectively. The experiment was conducted in completely randomized design with 3 replications. The highest green chili yield $\left(19.03 \mathrm{t} \mathrm{ha}^{-1}\right)$ was obtained from $\mathrm{T}_{2}$, which was statistically identical to $T_{1}$ and $T_{3}$ but significantly higher over $T_{4}$. Therefore, Kc values were calculated from the best performed treatment, $\mathrm{T}_{2}$. The estimated $\mathrm{Kc}$ values for green chili during rabi season found to be $0.42,0.78,1.27$ and 0.86 for initial, crop development, mid-season and late season stages, respectively. The Kc values derived from this experiment may be more accurate and better suited than the generalized ones under Bangladesh contexts and alike agro-climatic conditions. Thus the values determined from this study may be recommended for Bangladesh and similar climate elsewhere to estimate crop water requirement for chill.
\end{abstract}

Keywords: Crop coefficient, Evapotranspiration, Irrigation, Chili, lysimeter.

\section{INTRODUCTION}

Chili (Capsicum spp.) is an important spice cum vegetable crop grown in almost all parts of tropical and subtropical regions of the world. Chili is the largest produced spice crop in in Asia. It belongs to the family Solanaceae and originated from South and Central America where it was domesticated around 7000 BC. It is one of the major spices crop used in every kitchen in our country and eaten daily and widely used throughout tropical counties. Chili is grown in many parts of the world. Major chili growing countries are India, China, Ethiopia, Myanmar, Mexico, Peru, Vietnam, Pakistan, Ghana, and Bangladesh. In Bangladesh, chili is grown as cash crop. Its commercial production is largely concentrated in the district of Pabna, Faridpur, Chuadanga, for summer chili, Bhola, Panchgarh, Shariatpur, Jamalpur, Sirajgonj, Manikgonj, Chittagong and Noakhali for winter chili. In Bangladesh chilies are grown in about 1.02 lakh hectares of cultivated land. Our winter chili production is 1.36 lakh MT and total chili production is 1.74 lakh MT. Therefore, winter chili covers $78 \%$ of the total chili production. Chili production covers $10.54 \%$ of the total spices production of Bangladesh [5].

The average yield of chili in Bangladesh is 1.34 t/ha for dry and $9 \mathrm{t} / \mathrm{ha}$ for green chill (BBS 2016) which is very low compared to other country where $2-3$ t/ha and 10-15 t/ha dry and green chili, respectively in India [10].

However, due to high rates of evaporation and low levels of precipitation, the significance of irrigation is vital for attaining and sustaining optimum productivity. Because of our limited knowledge of crop water use, flood irrigation without scheduling is still the main irrigation practice, which is not only a non-efficient use of water resources but also has the possibility for increasing the risk of groundwater contamination because a large number of solutes could be leached below the root zone using this irrigation practice [12].

Kruger et al., [8] reported that the optimum use of irrigation can avoid the leaching of nutrients into deeper soil layer. One of the limitations in chili cultivation in Bangladesh is the lack of irrigation due to scarcity of water. The irrigation scheduling was done on the basis of

Corresponding Author: Md. Nazmul Islam, International University of Business Agriculture and Technology, IUBAT,

E-mail : arbnazmul@gmail.com 
critical growth stages where water requirement was not properly estimated as a result much of applied water may be lost through percolation, runoff and evapotranspiration. Thus, estimation of water requirement of crop is an inevitable task. The crop coefficient value is better tool for optimization of crop water requirement throughout the growing period, which would ensure better water use efficiency [1]. Thus, Kc appears as the most important factor in context of intensive and precision agriculture.

The water requirement of chili changes depending on soil and climatic factors. If paucity of water is observed in soil before planting, irrigation is required but during rainy season irrigation should be done on the basis of moisture of soil. Lysimeters are the important tools in soil-plant-atmosphere research because they can directly measure evapotranspiration and facilitate water, fertilizer and solute balance studies [11]; [4]. Reliable measurements of drainage quantity and content are generally very difficult under field conditions while much easier to make using lysimeters. For instance, water percolates trough the root zone may be collected and analyzed when using percolation lysimeters, while changes in water content can be determined by weighing lysimeters [11]; [21].

The calculation of water requirements by means of lysimeter method is relatively simple. The basic formula for the calculation reads as follows:

$$
\mathrm{ET} \text { crop }=\mathrm{Kc} \times \mathrm{ET}_{0}
$$

Where; ET crop = the water requirement of a given crop in mm per unit of time e.g. mm day ${ }^{-1}, \mathrm{~mm} \mathrm{month}^{-1}$ or season ${ }^{-1}$. $\mathrm{Kc}=$ the "crop factor"; $\mathrm{ET}_{0}=$ the "reference crop evapotranspiration" in mm per unit of time e.g. $\mathrm{mm} \mathrm{day}^{-1}$, $\mathrm{mm} \mathrm{month}^{-1}$ or mm season ${ }^{-1}$.

Crop water requirement: $\mathrm{ET}$ crop $=\mathrm{Kc} \times \mathrm{ET}_{0}$

Values of $\mathrm{K}_{\mathrm{c}}$ are available in literature [3], but none is recommended for a specific location. It is better to determine the factor locally. Physiological characteristics of crop varieties differ under different soil and climatic conditions, thus showing varying physiological demands including crop water requirements (crop ET). The determination of crop coefficient lies in the determination of stage-wise crop ET and estimation of reference crop evapotranspiration. The most reliable method for determining the crop coefficient values is the lysimetric study. Many scientists have studied crop ET using lysimeters [20]. Climatological approaches of estimating ET are available in literature [2]. These approaches are based on the empirical data and required local calibration which is impossible without lysimeter. Therefore, the objectives of this experiment were to find out the crop co-efficient values $(\mathrm{Kc})$ for winter chili using drainage lysimeter and to estimate the water requirement of chili to be grown in dry winter season.

\section{MATERIALS AND METHODS}

The experiment was conducted at Soil Science research field of Bangladesh Agricultural Research Institute (BARI), Gazipur, Dhaka, Bangladesh during the period from 22 November 2017 to 07 April 2018. The experimental field situated at $24^{\circ} 05^{\circ} \mathrm{N}$ latitude and $90^{\circ}$ $25^{\prime}$ E longitudes having an elevation of $8.2 \mathrm{~m}$ from sea level.

The micro-lysimeter were constructed recently by Soil Science Division, Bangladesh Agricultural Research Institute (BARI) and situated at Soil Science research field, Gazipur. It has 12 tanks spaced at equal distance $(4 \mathrm{~m})$. The tanks were installed in 3 lines taking 4 in each line for the 3 replicate measurements. The lysimeter tank has 1 meter square area with effective soil depth of $100 \mathrm{~cm}$ followed by a perforate Stainless Steel (SS) sheet. Below the SS sheet, 2 meshes of no. 20 and 40 are placed. Below the mesh, a $15 \mathrm{~cm}$ thick coarse gravel packs are sandwiched. Then a water receiving reservoir was provisioned where the excess water from the upper parts are discharged. Then the discharged water goes through the drainage piping to the reservoir.

Each lysimeter tank is provided with a stainlesssteel pipe of $1.75 \mathrm{~cm}$ diameter which serves as an air vent. The vent is inserted up to the gravel layer and is provided with a cap at the top end. Below the lysimeter tank a $7.5 \mathrm{~cm}$ thick concrete layer is provided followed by a $7.5 \mathrm{~m}$ thick stone soling. A $13 \mathrm{~cm}$ thick brick wall was constructed around the lysimeter tank leaving $5 \mathrm{~cm}$ sand pack between the tank and the wall. The brick wall is constructed at a depth of $30 \mathrm{~cm}$ from the soil surface. Twenty-seven days old chili (cv. BARI Morich 3) seedlings were transplanted in lysimeter tanks, each having $1 \mathrm{~m}^{2}$ area on 30 November 2017. Also, to maintain a similar environment, the same crop was grown in the lands surrounding the tanks. The soil was clay loam with field capacity and bulk density, $28.53 \%$ and $1.48 \mathrm{~g} \mathrm{cc}^{-1}$, respectively.

There were four treatments as follows:

$$
\begin{aligned}
& \mathrm{T}_{1}=\text { Irrigation up to } \mathrm{FC} \text { at } 10 \text { days interval } \\
& \mathrm{T}_{2}=\text { Irrigation up to } \mathrm{FC} \text { at } 15 \text { days interval } \\
& \mathrm{T}_{3}=\text { Irrigation up to } \mathrm{FC} \text { at } 20 \text { days interval } \\
& \mathrm{T}_{4}=\text { Irrigation up to } \mathrm{FC} \text { at } 25 \text { days interval }
\end{aligned}
$$

As lysimeter has 12 tanks in operation, therefore the experiment was set up in a completely randomized design with 3 replications. The crop was fertilized with $\mathrm{N}_{110} \mathrm{P}_{38} \mathrm{~K}_{72} \mathrm{~S}_{21} \mathrm{Zn}_{2} \mathrm{~B}_{1.2} \mathrm{~kg} \mathrm{ha}^{-1}$ and cow dung @ $10 \mathrm{tha}$ ${ }^{1}$. Entire amount of cow dung, TSP, gypsum, boric acid and $2 / 3 \mathrm{rd}$ of MoP was applied during the final land preparation. Urea as a source of nitrogen was applied in 4 equal splits at 5, 25, 50 and 75 days after transplanting (DAT). The rest of MoP was applied with third dose of 
urea at 50 DAT. The crop was irrigated up to field capacity for $30 \mathrm{~cm}$ depth rooting zone as per treatment schedule. Measured quantity of water depending on the FC value was applied. Soil moisture was measured before irrigation. As per treatment, 12, 8, 6 and 4 irrigations were required for $T_{1}, T_{2}, T_{3}$ and $T_{4}$, respectively. Vertimec @ $1 \mathrm{ml}$ L-1 and Succexx @ $2 \mathrm{ml}$ L-1 were sprayed for controlling mite and chiling injury, respectively. Percolate was collated whenever it deposited in the buckets placed underneath of the drainage outlets coming from each lysimeter tank. In this way 3 collections after $2^{\text {nd }}, 3^{\text {rd }}$ and $4^{\text {th }}$ irrigation was possible during the growing period of chili. The crop showed luxuriant growth especially for the treatment $\mathrm{T}_{1}$ and $\mathrm{T}_{2}$. Harvesting of green chili was started on 18 March 2018 and ended on 7 April having 4 pickings altogether. Climatic data, such as maximum and minimum temperatures, air humidity, sunshine hours/day and wind speed were collected from the nearest meteorological station. The location information like elevation, latitude, and longitude were also collected. All these data were then used to estimate the potential evapotranspiration $\left(\mathrm{ET}_{0}\right)$. Crop data like plant height, number of fruits per plant, fruit length, fruit breadth and green chili yield were recorded and statistically analyzed. The part of rainfall collected as drainage and the change in stored soil moisture during the period under consideration were subtracted from the applied water to obtain crop evapotranspiration $\left(\mathrm{ET}_{\mathrm{c}}\right)$. The crop evapotranspiration for the specified period was estimated using the following equation:

$$
\mathrm{ET}_{\mathrm{ct}}=\mathrm{W}_{\mathrm{a}}-\left(\mathrm{D}_{\mathrm{w}} \pm \boldsymbol{\Delta} \mathrm{S}_{\mathrm{s}}\right)
$$

Where; $\mathrm{ET}_{\mathrm{ct}}=$ crop evapotranspiration in $\mathrm{mm}$ for time, $\mathrm{t}$ $\mathrm{W}_{\mathrm{a}}=$ applied water, $\mathrm{mm}+$ rainfall, $\mathrm{mm}$ for time, $\mathrm{t}$ $\mathrm{D}_{\mathrm{w}}=$ drainage water, $\mathrm{mm}$ for time, $\mathrm{t}$

$\Delta \mathrm{S}_{\mathrm{s}}=$ stored soil moisture, $\mathrm{mm}$ for time, $\mathrm{t}$

Then from the potential evapotranspiration $\left(\mathrm{ET}_{0}\right)$ estimated for the specified period, the value of $\mathrm{K}_{\mathrm{c}}$ for the period was determined from the ratio, $\mathrm{ET}_{\mathrm{c}} / \mathrm{ET}_{0}$.

Percolates were collected whenever they were deposited in the buckets placed underneath of the drainage outlets coming from every lysimeter tank. In this way, 3 collections after $2^{\text {nd }}, 3^{\text {rd }}$ and $4^{\text {th }}$ irrigations were done during the growing period of chili.

The mean data with replicate observations were analyzed statistically following Statistics 10 Software. The treatment means were separated by the Least Significant Difference (LSD) test. Regression analysis was done using Microsoft Excel Version 7.

\section{RESULTS AND DISCUSSION}

Result presented in Table 1 showed that the crop performed well for $\mathrm{T}_{2}$ treatment where 8 irrigations up to FC at every 15 days interval were applied. The highest green chili yield (19.03. $\mathrm{t} \mathrm{ha}^{-1}$ ) was obtained from $\mathrm{T}_{2}$, which was statistically identical to $T_{1}$ and $T_{3}$ but significantly higher over $\mathrm{T}_{4}$. Similar trend of result was observed for fruit weight per plot where the highest fresh fruit weight (1903.3 $\mathrm{g} \mathrm{plot}^{-1}$ ) was recorded from $\mathrm{T}_{2}$ and the lowest (1286.7 $\mathrm{g} \mathrm{plot}^{-1}$ ) from $\mathrm{T}_{4}$ (Table 1). However, there was no significant difference for yield components like plant height, fruit length, fruit breadth and fruits per plant even though $T_{2}$ performed better than other treatments. As crop performance was the best for $\mathrm{T}_{2}$ so irrigation interval set for this treatment provided relatively better environment for plants to produce the highest yield. Therefore, this treatment $\left(\mathrm{T}_{2}\right)$ was selected for the determination of Kc value. The optimum crop coefficient at different growth stages are recommended to calculate from the best growing plants producing the highest yields [3]. Therefore, all calculations for the determination of crop water requirement were based on the performance of treatment, $\mathrm{T}_{2}$ and are presented in (Table 2 and 3 ).

Irrigation water was applied depending on the moisture content for a certain growing period to raise it up to FC level (28.53\%). From Table 2, it was observed that the applied irrigation water for initial, development, mid-season stages was 51, 76, 170 and $60 \mathrm{~mm}$, respectively for initial, development, mid-season and late season stage. After and second irrigation $5.9 \mathrm{~mm}$ percolate was collected while for the third and fourth irrigation the collected leachate was $3.65 \mathrm{~mm}$. Due to addition of optimum water on the basis of FC there was a positive balance of moisture storage except at midseason and late season stage. For the mid-season stage, the crop might have absorbed water from the stored soil moisture as deficit caused by higher evapotranspiration at later growth stage. Ultimately, storage soil moisture fell down to $-15.2 \mathrm{~mm}$, which signified that irrigation interval (15 days) set for this treatment may not suit well for March and April. For this reason plants for $T_{3}$ and $T_{4}$ treatments suffered from moisture stress at later growth stage. The crop ET for $\mathrm{T}_{2}$ found to be 22.3, 71.6, 185.38 and $77.23 \mathrm{~mm}$ for initial, development, mid-season and late season stage, respectively (Table 2). From this crop ET, the cumulative crop ET was estimated and trend line is represented in Fig.1. However, there was a second order polynomial relationship $\left(\mathrm{R}^{2}=0.997 * *\right)$ between cumulative crop ET and crop growth stages (days after transplanting) (Fig.2). Using local climatic condition, the reference crop evapotranspiration $\left(\mathrm{ET}_{0}\right)$ was calculated as 53.1, 91.8, 145.5 and $89.8 \mathrm{~mm}$ for initial, development, mid-season and late season stage, respectively. Thus the Kc value for chill found to be $0.42,0.78,1.27$ and 0.86 for initial, development, midseason and late season stage, respectively. Indeed, locally determined $\mathrm{Kc}$ values are preferable to generalized standard values to estimate location specific crop evapotranspiration. However, growth stage wise Kc values of green chill are depicted in Fig. 3. 


\section{CONCLUSIONS}

The highest green chili yield (19.03 $\left.\mathrm{t} \mathrm{ha}^{-1}\right)$ was obtained from treatment, $\mathrm{T}_{2}$ which followed Irrigation up to $\mathrm{FC}$ at 15 days interval. The crop coefficient $(\mathrm{Kc})$ values for green chili during winter season found to be $0.42,0.78$, 1.27 and 0.86 for initial, development, midseason and late season stage, respectively. The optimum crop ET viz. the water requirement for winter chili found to be 22.3, 71.6, 185.38 and $77.23 \mathrm{~mm}$ for initial, development, mid-season and late season stage, respectively for the study area as well as soil alike and almost similar kind of climatic condition. Since these Kc values were determined under local agro-climatic conditions, so they may be more accurate and better suited. The $\mathrm{Kc}$ values of chili as derived from this experiment may be useful to the irrigation expert, agricultural extension personnel as well as chili growers for estimating the water requirement of chili in order to save water resource from losses and to provide optimum level of water for luxuriant growth of chill. Thus the values determined from this study may be recommended for Bangladesh and similar climate elsewhere to estimate crop water requirement for chill.

\section{REFERENCES}

[1] Begum R.A., N.C.Shil, A.T.M.A.I. Mondol, M.J. Alam and A.J. Mila. Determination of Crop Coefficient Values of Broccoli and estimation of leaching loss of nutrients by Drainage Lysimeter. 2017. Annual research report 2016-2017. Soil Science Division. Bangladesh Agricultural Research Institute. Pp -01-09.

[2] Ben Asher, J., A. D. Mathias and A. W. Warrick. 1983. Assessment of evapotranspiration from bare soil by infrared thermometry. Soil. Sci. Soc, Am. J. 47: 185-191.

[3] Doorenbos, J. and W.O. Pruitt. 1977. Guidelines for predicting crop water requirements. Irrigation and Drainage paper No.24., FAO, Rome.

[4] Hillel, D., Gairon, S. Falkenflug, V. and Rawitz, E. 1969. New design of a low-cost hydraulic lysimeter system for field measurement of evapotranspiration. Isr J. Agric. Res. 19(2):57-63.

[5] Hoq, M.S. and M.I. Omar. 2015. Production and marketing of green chili in two copious district of Bangladesh. Research gate. Vol. 1. ISSU.18. ISSN: 2319-2801

[6] Khan, B.R., M. Mainuddin and M.N. Molla. 1992. Design and construction of a set of lysimeters for study of evapotranspiration of different crops. Irrigation and Water Management Division, BARI, Gazipur. Pp. 42.

[7] Klocke, N.L., Todd, R.W. Hergert, G.W. Watts, W.G. and Parkhurst, A.M. 1993. Design, installation, and performance of percolation lysimeters for water quality sampling. Trans. ASAE 36:429-435.

[8] Kruger E., G. Schmidt, U. Bruckner. 1999. Scheduling strawberry irrigation based upon tensiometer measurement and a climatic water balance model. Scientia horticulturae. Volume 81, Issue 4. Pages 409-424

[9] Michael. A.M. 1990. Irrigation theory and practice. Vikas Publishing Home Pvt.Ltd., New Delhi 11014. Pp. 801.

[10] TNAU Agritech Portal, 2015. Horticulture: Vegetable: Chili

[11] Van Bavel, C.H.M. 1961. Lysimetric measurement of evapotranspiration rates in the eastern United States. Soil Sci. Soc. Am. Proc. 25:138-141.

[12] Zeng W., X. Chi, W. Jingwei, H. Jiesheng. 2014. Soil salt leaching under different irrigation regimes: HYDRUS-1D modeling and analysis. Journal of arid land. Volume 6, Issue 1, pp 44-58.

[13] Allen, R.G., L. S. Pereira, D. Raes, and M. Smith. 1998. Irrigation and Drainage Paper. p. 56. Crop evapotranspiration. Guidelines for computing crop water requirements. Food and Agricultural Organization of the United Nations, Rome. pp. 65.

[14] Ben Asher, J., A. D. Mathias and A. W. Warrick. 1983. Assessment of evapotranspiration from bare soil by infrared thermonetry. Soil. Sci. Soc. Am. J. 47: 185-191.

[15] Burman, R. D., P. R. Nixon. J. L. Wright and W. O. Prutt. 1983. Water requirements. In. design and operation of farm irrigation systems. ASAE Monograph No. 3, Edited by M. E. Jensen, St. Joseph. Michigan 49085. pp. 829.

[16] Doorenbos, J. and W.O. Pruitt. 1977. Guidelines for predicting crop water requirements. Irrigation and Drainage Paper No.24., FAO, Rome.

[17] Giriappa, S. 1983. Water use efficiency in agriculture, Oxford and IBH Publishing Co. Pvt. Ltd.

[18] Hensen, V.E., 0. W. Israyelsen and G. E. Stringham. 1979. Irrigation principles and practices. 4th Edition. John Willey \& Sons. New York. pp. 417.

[19] Hillel, D., Gairon, S. Falkenflug, V. and Rawitz, E. 1969. New design of a low-cost hydraulic lysimeter system for field measurement of evapotranspiration. Isr J. Agric. Res. 19(2):57-63.

[20] Khan, B. R., M. Mainuddin and M. N. Molla. 1992. Design and construction of a set of lysimeters for study of evapotranspiration of different crops. Irrigation and Water Management Division, BARI, Gazipur. pp. 42.

[21] Klocke, N.L., Todd, R.W. Hergert, G.W. Watts, W.G. and Parkhurst, A.M. 1993. Design, installation, and performance of percolation lysimeters for water quality sampling. Trans. ASAE 36:429-435. 
[22] Michael. A. M. 1990. Irrigation theory and practice. Vikas Publishing Home Pvt. Ltd., New Delhi 11014. pp. 801.

[23] Noor, S., Shil, N. C. and Hoque, M. A (ed.). 2012. Integrated nutrient management for Sustainable Crop Yield and Soil Fertility. p. 48-50.

[24] Roy, K.C., T.M.K.Anwar and M. Mainuddin. 1994. Response of maize to irrigation by pan evaporation method. Bangladesh J.Agril. Res. 19:(2) 125-133.

[25] Shani, U., Hanks, R.J. Bresler, E. and Oliveira, A.S. 1987. Field method for estimating hydraulic conductivity and matric potential-water content relations. Soil Sci. Soc. Am. J. 51:298-302.
[27] Tourdonnet, S., Meynard, J.M. Lafolie, F. Rogerestrade, J. Lagier, J. and Sebillotte, M. 2001. Nonuniformity of environmental conditions in greenhouse lettuce production increases the risk of $\mathrm{N}$ pollution and lower product quality. Agronomie 21:297-309.

[28] Ullah, M.Z., Karim, M.F., Bhuiyan, M.S.U. and Ali, M.H. 2002. Crop production environment and Management. Bonafide printers, Fakirarpul, Dhaka.

[29] Van Bavel, C.H.M. 1961. Lysimetric measurements of evapotranspiration rates in the eastern United States. Soil Sci. Soc. Am. Proc. 25:138-141.

[30] Wang, S., and Boulard, T. 2000. Measurement and prediction of solar radiation distribution in fullscale greenhouse tunnels. Agronomie 20:41-50.

[26] Shenkar, M., Ben-Gal, A. and Shani, U. 2003. Sweet corn response to combined nitrogen and salinity environmental stresses. Plant Soil 256:139-147. 